\title{
Transmission characteristics of allexiviruses by the eriophyid mite, Aceria tulipae (Keifer) (Acari: Eriophyidae) from naturally mixed infected garlic (Allium sativum L.)
}

\section{Faten Mansouri ( $\square$ feten.mansouri@live.fr)}

Ceska Zemedelska Univerzita v Praze https://orcid.org/0000-0002-8801-1972

\section{Katja R. Richert-Pöggeler}

Julius Kühn Institute: Julius Kuhn-Institut Bundesforschungsinstitut fur Kulturpflanzen

Mariusz Lewandowski

Warsaw University of Life Sciences: Szkola Glowna Gospodarstwa Wiejskiego w Warszawie Pavel Ryšánek

Czech University of Life Sciences Prague: Ceska Zemedelska Univerzita v Praze

\section{Research Article}

Keywords: Allexivirus, dry bulb mite, Allium sativum, virus transmission

Posted Date: April 8th, 2021

DOl: https://doi.org/10.21203/rs.3.rs-317884/v1

License: (c) (1) This work is licensed under a Creative Commons Attribution 4.0 International License. Read Full License

Version of Record: A version of this preprint was published at European Journal of Plant Pathology on April 13th, 2021. See the published version at https://doi.org/10.1007/s10658-021-02281-0. 


\section{Abstract}

The transmission characteristics of members of the genus Allexivirus to leek (Allium porrum L.) by its eriophyid mite vector, Aceria tulipae (Keifer), were studied. Prior to conducting transmission tests, colonies of nonviruliferous $A$. tulipae were established on healthy leek seedlings. A single A. tulipae transmitted the viruses with up to $50 \%$ efficiency but transmission efficiency increased when $>10$ mites per plant were used. Allexiviruses were acquired by $A$. tulipae after a minimum acquisition access period (AAP) of 30 minutes, whereas transmission tests suggest that a one hour inoculation access period (IAP) was needed for successful transmission. Allexiviruses were transmitted from garlic to leek plants by $A$. tulipae and mixed infections by more than one virus were observed. ShVX, GarV-A, -C, -D, and -B were detected in most inoculated plants, whereas other members of the genus (GarV-E, $-\mathrm{X}$, and GarMbFV) were found only occasionally. None of the mites that originated from eggs deposited on infected plants transmitted allexiviruses, indicating that the viruses are not transmitted transovarially. No latent period was demonstrated. Taken together, these data suggest a semipersistent mode of transmission of Allexivirus members by A. tulipae. The output of this study will assist in the better management of the vector and the associated diseases.

\section{Introduction}

A mosaic disease of Allium crops caused by viruses belonging to the genus Allexivirus (Family Alphaflexiviridae) was first described in 1970 by Razvjakina. The host range of allexiviruses comprises vegetable and ornamental Allium species mainly garlic, onion, and leeks (Van Dijk et al. 1991; Bampi et al. 2015; Paduch-Cichal and Bereda 2017). Eight species belonging to the genus have been reported to be restricted to alliums: Garlic virus A (GarV-A), Garlic virus B (GarV-B), Garlic virus C (GarV-C), Garlic virus D (GarV-D), Garlic virus E (GarV-E), Garlic virus X (GarV-X), Garlic-mite borne filamentous virus (GarMbFV) and Shallot virus X (ShVX) (Adam et al. 2012). Allexiviruses are single-stranded positive-sense RNA viruses and have flexuous filamentous particles with approximately $800 \mathrm{~nm}$ in length (Van Dijk et al. 1991).

Generally, allexiviruses cause very mild chlorotic stripes and mild mosaic in leaves of Allium species (Van Dijk et al. 1991). They cause yield loss and deterioration in the quality of several alliums (Cafrune et al. 2006). Single infection with either GarV-C or GarV-A resulted in a decrease in bulb weight and diameter (losses of approximately $15 \%$ and $5 \%$, respectively) (Cafrune et al. 2006). Single infection with GarV-D caused a reduction of $12.3 \%$ of garlic bulb weight and $6.7 \%$ of bulb caliber (Celli et al. 2016). Although infection of garlic crops by one allexiviruses could result in disease, yield losses were considerably more severe when allexiviruses occurred in mixed infections, especially in the presence of viruses from the genera Potyvirus (Family Potyviridae) and Carlavirus (Family Betaflexiviridae) (Conci et al. 2003).

Allexiviruses are transmitted by the eriophyid mite, Aceria tulipae (Keifer) (Van Dijk et al. 1991). Aceria tulipae, known as the dry bulb mite (DBM), was first found in tulip bulbs in 1938 and later in garlic and onion bulbs (Keifer, 1952). The host range of DBM includes plant species in the families Liliaceae, 
Amaryllidaceae, Melanthiaceae, and Asparagaceae (Kiedrowicz et al. 2017). The pest is considered one of the most important eriophyid plagues of bulbs (onion, garlic, and tulip). Infested plant parts are affected in multiple ways due to the activity of eriophyoid mites on the surface of bulbs and leaves. The feeding of eriophyoid mites on epidermal cells induces damage and deterioration of epidermal tissue and promotes virus transmission (Stenger at al. 2016). Consequently, bulb drying or decay, leaf twisting, curling, and discoloration of Allium crops are often observed (Debnath and Karmakar 2013). It was reported that high infestations of garlic cloves can result in a 32\% loss in bulb crops (Budai et al. 1997; Debnath and Karmakar 2013). High population densities of DBM have been reported on the bulb segment and middle sections of leaves (Sapáková et al. 2012; Beltran 2020). Once established on bulbs or leaves, mites can develop high population density. Courtin et al. (1999) reported that DBM develops from egg to egg within eight days under ideal environmental conditions $\left(25^{\circ} \mathrm{C}, 80 \%\right.$ relative humidity $)$ and in this time develops four stages: eggs, larva, nymph, and adults, what is typical for eriophyid (Manson and Oldfield 1996). Moreover, this pest may easily spread by crawling to neighboring plants, through insects, airflow, and irrigation water (Debnath and Karmakar 2013; Kiedrowicz et al. 2017).

Previous records about the virus vector $A$. tulipae provided limited information regarding the transmission characteristics of allexiviruses. Studies on the mite's capabilities as a virus vector are demanding because of the difficulties in rearing healthy mite colonies and manipulating individual mites. One study suggested that viruses are only acquired by the first and the second instar nymphs and mites can transmit allexiviruses up to eight days after they acquired the virus (Ahmed and Benigno 1985). However, details of the transmission mechanism of allexiviruses have not been described yet. On the other hand, several studies on eriophyid mites have described their transmission of plant viruses as semipersistent (Orlob 1966; Gispert et al.1998; Kulkarni et al. 2002). The semipersistent manner is characterized by an acquisition period of minutes to hours and the virus can be retained for as long as few days but it is lost during molting (Bhat and Rao 2020). In the current study, we started a series of experiments to determine the hallmarks of virus transmission by eriophyoid mites comprising the acquisition access period (AAP), the inoculation access period (IAP), as well as the virus retention of allexiviruses from mixed infected plants.

\section{Material And Methods}

Plant material. Leek plants (Allium porrum L.) were established from seeds and were grown and maintained in growth chambers at $25^{\circ} \mathrm{C}$ on a $16 \mathrm{hr}$ photoperiod, with a constant $80 \%$ relative humidity $(\mathrm{RH})$. Colony plants were regularly tested for allexiviruses and checked for possible contamination by mites. None of these plants was found infected with allexiviruses during the study. All experimental plants were covered individually with mite-proof polyamide cages with $40 \mu \mathrm{m}$ in diameter mesh and maintained in separate growth chambers operating under the above-described temperature and light conditions.

Garlic bulbs bought from a farmer's market were screened for the presence of mites and tested for allexiviruses. Several cloves with high mite infestations (> 1000 mites per clove) were placed in paper 
bags and kept in a dark storage room $\left(25^{\circ} \mathrm{C}, 80 \% \mathrm{RH}\right)$ for further experiments.

Mite colonies. Mites used during experiments were obtained from infested garlic cloves bought from a farmer's market and stored in paper bags, as described above. In all transmission experiments, mites were handled using a human eyelash affixed to a six cm-long wooden stick under a stereomicroscope. Adult mites were carefully taken to avoid their injury and transferred to young leek leaves under an adjacent stereomicroscope. Leek plants were immediately covered with mite-proof polyamide cages and carefully moved to growth chambers $\left(25^{\circ} \mathrm{C}, 80 \% \mathrm{RH}\right)$.

To obtain nonviruliferous $A$. tulipae, eggs were collected from garlic cloves and transferred to allexiviruses-free and mite-free leek leaves as confirmed by reverse transcription polymerase chain reaction (RT-PCR). For initial culture of $A$. tulipae, $5 \times 5 \mathrm{~mm}$ pieces were cut out from leek leaves and were placed into Plexiglas ${ }^{\circledR}$ plates containing an artificial culture medium. The in vitro MS medium was prepared according to the method described by Murashige and Skoog (1962) and modified by KarpickaIgnatowska et al. (2020). Plexiglas plates were covered with white paper to reduce the intensity of light that might damage the eggs and placed in a growth chamber $\left(25^{\circ} \mathrm{C}, 80 \% \mathrm{RH}\right)$. After seven days, eggs were hatched and nymph and/or adults $A$. tulipae stages were observed. Mites were then carefully transferred onto three-week-old leek plants, caged, and placed into a growth chamber $\left(25^{\circ} \mathrm{C}, 80 \% \mathrm{RH}\right)$. The same experiment was repeated a few times to obtain enough mite colonies. To ensure that mite colonies originating from eggs, were nonviruliferous, plants were assayed for viruses 21 days post-inoculation (pi) with mites and again 42 days pi.

To test the transmission of allexiviruses from mixed infections, viruliferous mites obtained from Allexivirus-infected garlic were used in most experiments. To obtain mite-free garlic plants, garlic cloves were put into hot water at temperatures of $40^{\circ} \mathrm{C}$ for 20 minutes, to eliminate mite infestation. Each garlic clove was then planted and caged. Infected garlic plants were put into a separate growth chamber $\left(25^{\circ} \mathrm{C}\right.$, $80 \% \mathrm{RH}$ ); later garlic leaves were checked for mite presence, tested for allexiviruses and used for further experiments.

Transmission tests. Virus-free and mite-free three-week-old leek plants maintained in the growth chamber $\left(25^{\circ} \mathrm{C}, 80 \% \mathrm{RH}\right)$ were used to determine transmission efficiency, acquisition/inoculation period, and retention of the virus. To test the acquisition access period (AAP), nonviruliferous $A$. tulipae were allowed to feed on Allexivirus-infected, mite-free garlic leaves for $5 \mathrm{~min}, 15 \mathrm{~min}, 30 \mathrm{~min}, 1 \mathrm{hr}$ (hours), 5hr, $24 \mathrm{hr}$, and 48hr. After each acquisition period, a group of 10 mites was transferred onto healthy three-week-old leek seedlings.

Virus-free and mite-free leek seedlings were also used to determine the inoculation access period (IAP). A group of 10 mites was transferred from infected garlic to individual healthy leek seedlings and allowed to feed for 30min, 1, 5, 24, and $48 \mathrm{hr}$. Following the respective time, mites were terminated by spraying plants using Substral acaricide (active ingredient acetamiprid used at 0,005\% concentration). IAP and AAP experiments for each given period were repeated at least two times; In each repetition, five to ten leek plants were used and kept in separate growth chambers. Leek plants were monitored for the absence of 
mites/symptoms and assayed for allexiviruses three weeks pi. For each experiment, two plants were used as negative control.

For virus retention, nonviruliferous mites were fed on Allexivirus-infected garlic bulbs for $24 \mathrm{hr}$. A group of 10 mites were then transferred serially three times to healthy leek seedlings for IAP of 1,5 , and $24 \mathrm{hr}$. Five plants were used for virus retention in each transfer; plants were caged and assayed for allexiviruses 3 weeks pi.

To determine the number of mites required to obtain $100 \%$ virus transmission, adult mites reared on Allexivirus-infected garlic cloves were transferred onto healthy three-week-old leek seedlings, either singly or in groups of 5,10 , and 20 mites. Mite-inoculated leek plants were then caged and assayed for allexiviruses 3 weeks pi.

Detection of viral infection. All experimental plants were assayed for presences of allexiviruses by looking for typical virus symptoms illustrated by mosaic and chlorotic patterns and leaf deformations and confirmed by RT-PCR. RT-PCR tests were first done using degenerate Allexivirus primers (Chen et al. 2004). Then positive samples were tested using specific primers for the detection of GarV-A, $-B,-C,-D,-E,-X$, ShVX (Chodorska et al. 2014) and GarMbFV (Park et al. 2005). Reverse transcription was performed using

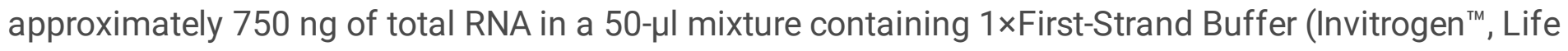
Technologies, Gaithersburg, MD, USA), $0.5 \mu \mathrm{g}$ random hexamers (Roche Diagnostics, Mannheim, Germany), 0.5 mM dNTP, 4 mMDTT (Invitrogen ${ }^{\text {TM }}$, Life Technologies) and 140 U Mu-MLV Reverse Transcriptase (Invitrogen ${ }^{\mathrm{TM}}$, Life Technologies) for $55 \mathrm{~min}$ at $42^{\circ} \mathrm{C}$, with a final incubation at $70^{\circ} \mathrm{C}$ for 10 $\min$.

PCR was carried out in the PTC 200 thermal cycler (BIORAD) and the cycling parameters were as follows: Initial denaturation at $94^{\circ}$ for $5 \mathrm{~min}$, followed by 35 cycles of denaturation at $94^{\circ} \mathrm{C}$ for $30 \mathrm{~s}$, annealing for $30 \mathrm{~s}$ at different temperatures according to primers used (see Chodorska et al. 2014; Park et al. 2005), extension at $72^{\circ} \mathrm{C}$ for $45 \mathrm{~s}$ and a final extension at $72^{\circ} \mathrm{C}$ for $7 \mathrm{~min}$. The PCR-amplified fragments were visualized after electrophoresis on ethidium bromide-stained $1.5 \%$ agarose gels.

\section{Results}

Nonviruliferous A. tulipae colonies. Leek plants inoculated with mites generated from eggs tested negative for allexiviruses by RT-PCR. Leeks inoculated with $A$. tulipae generated mite colonies within weeks. After two months, high densities of mites were observed and plants showed symptoms triggered by mite feeding and propagation activities such as twisting, curling, and discoloration of leaves.

Acquisition access period. Nonviruliferous mites acquired allexiviruses and transmitted the viruses to two healthy leek plants after 30 minutes (33\% of tested plants) (Table 1). When mites were provided with an AAP $>5$ hours, transmission to healthy leek plants increased ( $91 \%$ of tested plants). None of the mites provided with a 5- or 15-minute AAP were able to successfully inoculate a healthy leek plant, indicating that a minimum AAP of 30 minutes was required for $A$. tulipae to acquire allexiviruses. 
Table 1 Transmission of allexiviruses to healthy leek seedlings by a group of 10 Aceria tulipae given different acquisition access periods (AAP) and a 24-hour inoculation access period (IAP)

\begin{tabular}{|llll|}
\hline \multicolumn{4}{|l|}{ No. of infected plants/ No. of plants (\% transmission)[a] } \\
\hline AAP[b] & Exp. 1 & Exp. 2 & mean (\%) \\
\hline $5 \mathrm{~min}$ & $0 / 3(0)$ & $0 / 3(0)$ & 0 \\
\hline $15 \mathrm{~min}$ & $0 / 5(0)$ & $0 / 5(0)$ & 0 \\
\hline $30 \mathrm{~min}$ & $2 / 4(50)$ & $0 / 5(0)$ & 33 \\
\hline $1 \mathrm{hr}$ & $4 / 5(80)$ & $0 / 5(0)$ & 40 \\
\hline $5 \mathrm{hr}$ & $3 / 5(60)$ & $1 / 5(20)$ & 40 \\
\hline $24 \mathrm{hr}$ & $6 / 6(100)$ & $4 / 5(80)$ & 91 \\
\hline
\end{tabular}

[a] No: number; Exp: experiment; min: minutes; hr: hour(s)

[b] A. tulipae exposed to Allexivirus-infected garlic for the times indicated. Mite feeding was not terminated after transferring onto test plants

Inoculation access period. None of the leek plants exposed to viruliferous $A$. tulipae for an IAP of 30 minutes became infected (Table 2). However, plants exposed to viruliferous $A$. tulipae for more than $1 \mathrm{hr}$ developed curling and mosaic symptoms and these plants tested positive for allexiviruses by RT-PCR using both degenerate and specific primers.

Table 2 Transmission of allexiviruses to healthy leek seedlings by a group of 10 Aceria tulipae reared on Allexivirus-infected garlic and given different inoculation access periods (IAP)

\begin{tabular}{|lllll|}
\hline \multicolumn{5}{|l}{ No. of infected plants/ No. of plants (\% transmission)[a] } \\
\hline IAP[b] & Exp. 1 & Exp. 2 & Exp. 3 & mean (\%) \\
\hline $30 \mathrm{~min}$ & $0 / 3(0)$ & $0 / 4(0)$ & $\mathrm{nt}[\mathrm{c}]$ & 0 \\
\hline $1 \mathrm{hr}$ & $2 / 4(50)$ & $1 / 3(33)$ & $\mathrm{nt}$ & 43 \\
\hline $5 \mathrm{hr}$ & $2 / 5(40)$ & $3 / 5(60)$ & $\mathrm{nt}$ & 50 \\
\hline $24 \mathrm{hr}$ & $4 / 9(44)$ & $4 / 6(66)$ & $9 / 10(90)$ & 68 \\
\hline $48 \mathrm{hr}$ & $5 / 6(83)$ & $5 / 7(71)$ & $8 / 10(80)$ & 78 \\
\hline
\end{tabular}

[a] No: number; Exp: experiment; min: minutes; hr: hour(s)

[b] Mite feeding was terminated by spraying test plants with acaricide after each IAP period [c] nt: not tested 
Virus Retention. A group of 10 mites reared on Allexivirus-infected garlic cloves for $24 \mathrm{hr}$ transmitted allexiviruses to RT-PCR virus-free and mite-free leeks for up to two serial transfers when they were allowed to feed for 5 and $24 \mathrm{hr}$, (representing $40 \%$ and $80 \%$ of the tested plants, respectively) (Table 3 ). On the second transfer, only $40 \%$ of the plants were infected and none were infected after the third transfer. When mites were allowed to feed for $1 \mathrm{hr}$, one out of five leek plants were infected; However, none of the plants were infected after the second and third transfer, confirming that continuous feeding on a plant for more than one hour is essential for successful virus transmission

Table 3 Retention of allexiviruses by Aceria tulipae after given different inoculation access periods (IAP) and then serially transferred to healthy leek seedlings[a]

\begin{tabular}{|llll|}
\hline & \multicolumn{3}{l}{ No. Infected plants/ No. Plants (\% transmission) [b] } \\
\hline IAP (hr) [c] & Transfer 1 & Transfer 2 & Transfer 3 \\
\hline 1 & $1 / 5(20)$ & $0 / 5(0)$ & $0 / 5(0)$ \\
\hline 5 & $2 / 5(40)$ & $1 / 5(20)$ & $0 / 5(0)$ \\
\hline 24 & $4 / 5(80)$ & $1 / 5(20)$ & $\mathrm{nt}[\mathrm{d}]$ \\
\hline
\end{tabular}

[a] Mites were fed on Allexivirus-infected garlic leaves for 24 hours

[b] Serial transfers; No: number

[c] Times of mite feeding on healthy leek seedlings before transferring to another healthy leek seedlings; hr: hours

[d] nt: not tested

Transmission efficiency. When a single viruliferous A. tulipae was transferred from Allexivirus-infected garlic cloves to healthy leek seedlings, only $22 \%$ of the plants were successfully infected. However, virus transmission increased when plants were inoculated with more than 5 mites on the leaf (Table 4). Virus infected leek plants showed in addition to curling symptoms due to mite infestation, increased yellowing, and chlorotic strikes on the leaves.

Table 4 Transmission efficiency of allexiviruses to healthy leek seedlings by different numbers of Aceria tulipae that were reared on Allexivirus-infected garlic bulbs[a] 


\begin{tabular}{|lllll|}
\hline & \multicolumn{4}{l}{ No. of infected plants/ No. of plants (\% transmission) } \\
\hline No. of $\boldsymbol{A}$. tulipae/ plant & Exp. 1[b] & Exp. 2 & Exp. 3 & mean (\%) \\
\hline 1 & $4 / 8(50)$ & $1 / 10(10)$ & $\mathrm{nt}[\mathrm{c}]$ & 22 \\
\hline 5 & $5 / 9(55)$ & $4 / 10(40)$ & $\mathrm{nt}$ & 47 \\
\hline 10 & $8 / 12(66)$ & $8 / 10(80)$ & $4 / 5(80)$ & 80 \\
\hline 20 & $10 / 12(83)$ & $9 / 10(90)$ & $5 / 5(100)$ & 89 \\
\hline
\end{tabular}

[a] Different mite number were transferred into healthy leek seedlings caged and tested 3 weeks postinoculation

[b] No: number; Exp: experiment

[c] nt: not tested

Virus detection. In garlic cloves and leaves, allexiviruses (GarV-A, -B, -C, -D, -E, -X, GarMbFV, and ShVX) could be identified (Table 5). For each experiment (AAP, IAP, virus retention, and transmission efficiency), leek plants also tested positive for allexiviruses using degenerate primers and specific primers for each species. During this study, all infected and mite-inoculated leek plants were found to be mixed infected with more than one Allexivirus. The most frequently detected Allexivirus present in mixed infections was ShVX, accounting for $64 \%$ of the total infected leek samples (84 infected with ShVX/ 130 total infected plants) indicating positive detection, followed by GarV-A and GarV-B with 41\% (54/130) and 38\% $(50 / 130)$ of the total samples testing positive, respectively. The least detected viruses were GarV-X and GarV- E, with detection occurring in only 7 (5\%) and $13(10 \%)$ plants of the total tested samples, respectively. GarV-D, GarV-C and GarMbFV were also detected in the inoculated leeks with an infection rate of $28 \%(37 / 130), 31 \%(41 / 130)$, and $21 \%(28 / 130)$, respectively (Table 5).

Table 5 Results of allexiviruses screening of mite-inoculated and infected leek plants 


\begin{tabular}{|c|c|c|c|c|c|c|c|c|c|}
\hline \multirow[t]{2}{*}{$\begin{array}{l}\text { Name of } \\
\text { experiment }\end{array}$} & \multirow{2}{*}{$\begin{array}{l}\text { Total } \\
\text { infected/ } \\
\text { total } \\
\text { tested } \\
\text { (\%)[a] }\end{array}$} & \multicolumn{8}{|c|}{ No. of plants infected by viruses[b] } \\
\hline & & ShVX & $\begin{array}{l}\text { GarV- } \\
\text { A }\end{array}$ & $\begin{array}{l}\text { GarV- } \\
\text { B }\end{array}$ & $\begin{array}{l}\text { GarV- } \\
\text { C }\end{array}$ & $\begin{array}{l}\text { GarV- } \\
\text { D }\end{array}$ & $\begin{array}{l}\text { GarV- } \\
\mathrm{E}\end{array}$ & $\begin{array}{l}\text { GarV- } \\
\text { X }\end{array}$ & GarMbFV \\
\hline $\begin{array}{l}\text { Acquisition } \\
\text { access } \\
\text { period }\end{array}$ & $\begin{array}{l}20 / 56 \\
(35)\end{array}$ & 11 & 10 & 9 & 10 & 5 & 3 & 1 & 7 \\
\hline $\begin{array}{l}\text { Inoculation } \\
\text { access } \\
\text { period }\end{array}$ & $\begin{array}{l}43 / 72 \\
(59)\end{array}$ & 26 & 14 & 12 & 10 & 14 & 6 & 2 & 9 \\
\hline $\begin{array}{l}\text { Retention } \\
\text { period }\end{array}$ & $\begin{array}{l}9 / 40 \\
(22)\end{array}$ & 7 & 5 & 3 & 1 & 3 & 0 & 0 & 1 \\
\hline $\begin{array}{l}\text { Transmission } \\
\text { Efficiency }\end{array}$ & $\begin{array}{l}58 / 91 \\
(63)\end{array}$ & 40 & 25 & 26 & 20 & 15 & 4 & 4 & 11 \\
\hline
\end{tabular}

[a] Total number of infected plants on the total tested plants in each experiment.

[b] Number of samples in which virus was found; No: Number.

ShVX $=$ Shallot virus $X$, GarV-A = Garlic virus $A$, GarV-B = Garlic virus B, GarV-C = Garlic virus C, GarV-D = Garlic virus D, GarV-E = Garlic virus E, GarV-X = Garlic virus $X$, GarMbFV = Garlic-mite borne filamentous virus.

\section{Discussion}

The present study showed that allexiviruses present in mixtures can be transmitted from garlic (Allium sativum L.) to leek ( $A$. porrum L.) by their major vector, Aceria tulipae. A similar study from Poland showed that a mixed infection of Garlic virus $B,-C$, $-D$, and $-X$ was successfully transmitted to leek plants by A. tulipae (Dąbrowska et al. 2020). According to our data, mixed infection with more than one Allexivirus was observed on mite-inoculated leek plants. ShVX, GarV-B, and GarV-A were the most transmitted viruses in the mite-inoculated leaves (Table 5). These viruses are the most economically important allexiviruses found in the Czech Republic (F. Mansouri, personal observations). Although limited data about the concentration of allexiviruses in infected garlic is available, some reports indicated that the concentration of allexiviruses in garlic cloves may depend on the season and that allexiviruses present in low concentration may be undetectable (Conci et al. 2002; Cafrune et al. 2006). Therefore, one can speculate that the transmission of some allexiviruses from the mixed infection is probably due to the unequal distribution in the bulb tissue. However, more studies are needed to further understand the distribution and concentration of these viruses in garlic crops.

To investigate $A$. tulipae's potential to transmit allexiviruses in greater detail, acquisition access period, inoculation access period, virus retention, and transmission efficiency were studied. Aceria tulipae required a minimum of a 30 min acquisition access period (AAP) to acquire allexiviruses and a one-hour inoculation access period (IAP) was required for successful transmission. Transmission efficiency of 
allexiviruses increased with increasing acquisition and inoculation access time, which has also been documented for Wheat streak mosaic virus (WSMV, genus Tritimovirus) and Triticum mosaic virus (TriMV, genus Tritimovirus) (Orlob1966; Knoell 2018). Based on the inoculation/acquisition access period, the transmission of allexiviruses may be considered semipersistent. Similar findings reported the transmission of Pigeon Pea sterility mosaic virus (PPSMV, genus Emaravirus) and Peach mosaic virus (PMV, genus Trichovirus) in a semi-persistent manner by their vector, Aceria cajani ChannaBasavannaand and Eriophyes Insidiosus Keifer \& Wilson, respectively (Gispert et al. 1998; Kulkarni et al. 2002). Transmission efficiency of allexiviruses via A. tulipae decreased as number of mites transferred decreased. Transmission efficiency was greatest with 10 adult mites transferred per plant, similar to results observed for PPSMV (Kulkarni et al. 2002). In contrast, relatively high transmission was observed by a single $E$. insidiosus mite compared to when the number of mites was increased (Gispert et al. 1998). This can be explained by the fact that different mite species may have different virus transmission efficiencies (Seifers 2002).

When newly hatched mites from eggs were transferred to healthy leek seedlings, symptoms observed on mite-infested leek plants included twisting and curling of leaves, which are typical symptoms of mite infestation (Debnath and Karmakar 2013). The observed phenotypes of leaf deformations are assumed to protect the free roaming and no gall forming mites from dehydration. Under suitable environmental conditions, mites can proliferate to high numbers (Sapáková et al. 2012). In addition, no leek plants developed mosaic symptoms and they tested negative for allexiviruses. Thus, we can conclude that allexiviruses are not transovarially transmitted. Several studies on eriophyid mite-borne viruses reported that viruses are not transmitted through the egg of their vector. WSMV was reported to be transmitted by larvae, nymph, and adults of Aceria tosichella Keifer, but not through eggs (Orlob1966; Sánchez-Sánchez et al. 2001). In addition, PPSMV and PMV also were not transovarially transmitted by their vectors (Gispert et al. 1998; Kulkarni et al. 2002).

This study is the first to document transmission characteristics of allexiviruses by their vector eriophyid mite $A$. tulipae, enhancing our understanding of the virus-vector relationship. Characterizing transmission for viruses infecting Allium crops is critical to better understand eriophyid vector transmission mechanisms and their influence on the epidemiology of viruses. Finally, the determination of the transmission mode is seminal for designing strategies to prevent virus spread and dissemination by their vector.

\section{Declarations}

Acknowledgement. The project was supported by the internal Grant Agency of the Czech University of Life Sciences Prague (CIGA) (Project No. 20182014) in the Czech Republic and PROM (International Scholarship Exchange of PhD Candidates and Academic Staff)/ NAWA (Polish National Agency for Academic Exchange), Warsaw University of Life Sciences.

\section{Compliance with ethical standards}


The research does not involve any human participants and/or animals. The materials in the article have not been published in whole or in part elsewhere and not currently being considered for publication in another journal. All authors have been personally and actively involved in substantive work leading to the manuscript and will hold themselves jointly and individually responsible for its content. The authors certify that the work carried out in this research followed the principles of ethical and professional conduct. All authors consent to this submission.

\section{Conflict of interest}

The authors declare that they have no conflict of interest.

\section{References}

Adams, M. J., Candresse, T., Hammond, J., Kreuze, J. F., Martelli, G. P., Namba, S., Pearson, M. N., Ryu, K. H., \& Vaira, A. M. (2012). Alphaflexiviridae. In A.M. Q. King, M. J. Adams, E. B. Carstens, \& E. J. Lefkowitz (Eds.), Virus taxonomy, classification and nomenclature of viruses. Ninth report of the international committee on taxonomy of viruses. Amsterdam: Elsevier Academic Press.

Ahmed, K. M., \& Benigno, D. A. (1984). Control of the eriophid mite Aceria tulipae Keifer, the cause of tangle-top malady and the vector of garlic mosaic virus. Indian Journal of Plant Protection, 12, 153-154.

Amrine, J. W. Jr., \& Manson, D. C. M. (1996). Preparation, mounting and descriptive study of eriophyoid mites. In: Lindquist, E.E., Sabelis, M.W. \& Bruin, J. (eds.) Eriophyoid Mites - Their Biology, Natural Enemies and Control. World Crop Pests Vol 6. Elsevier Science Publishing, Amsterdam, The Netherlands, 383-396.

Bampi, D., Reinsel, M. D., \& Hammond, J. (2015). Viruses present in ornamental Allium in the United States. In: Proceedings of the APS Annual Meeting 1st-5th August, Pasadena, California, USA, 513.

Beltran, M. J. B. (2020). Preliminary sampling of dry bulb mite, Aceria tulipae Keifer in native garlic in Ilocos Region, Luzon Island, Philippines. Archives of Phytopathology and Plant Protection, 53, 653-658.

Bhat A. I., \& Rao G. P. (2020). Transmission of Viruses Through Mites. In: Characterization of Plant Viruses. Springer Protocols Handbooks. Humana, New York, NY.

Budai C. S., Regos A., \& Szeredi A. (1997). The occurrence of onion leaf mite (Aceria tulipae Keifer) in garlic bulbs. Novenyvedelem, 33, 53-56.

Cafrune, E. E., Perotto, M. C., \& Conci, V. C. (2006). Effect of two Allexivirus isolates on garlic yield. Plant Disease, 90, 898-904.

Chen J., Zheng H. Y., Antoniw J. F., Adams M. J., Chen J. P., \& Lin, L. (2004). Detection and classification of allexiviruses from garlic in China. Archives of Virology, 149, 435-44. 
Celli, M. G., Perotto, M. C., Buraschi, D., \& Conci, V. C. (2016). Biological and molecular characterization of Garlic virus D and its effects on yields of garlic. Acta Horticulturae, 1143, 193-200.

Chodorska, M., Paduch-Cichal, E., Kalinowska, E., \& Szyndel, M. S. (2014). Assessment of Allexiviruses Infection in Garlic Plants in Poland. Acta Sci. Pol., HortorumCultus, 13, 179-186.

Conci, V. C., Lunello, P., Buraschi, D., Italia, R. R., \& Nome, S. F. (2002). Variations of Leek yellow stripe virus concentration in garlic and its incidence in Argentina. Plant Disease, 86, 1085-1088.

Conci, V. C., Canavelli, A., Lunello, P., Di Rienzo, J., Nome, S. F., Zumelzu, G., \& Italia, R. (2003). Yield losses associated with virus-infected garlic plants during five successive years. Plant Disease, 87, 1411-1415.

Courtin, O., Fauvel, G., \& Leclant, F. (2000). Temperature and relative humidity effects on egg and nymphal development of Aceria tulipae (K.) (Acari: Eriophyidae) on garlic leaves (Allium sativum L.). Annals of Applied Biology, 137, 207-211.

Dąbrowska E., Lewandowski M., Koczkodaj S., \& Paduch-Cichal E. (2020). Transmission of Garlic virus B, Garlic virus $C$, Garlic virus $D$ and Garlic virus $X$ by Aceria tulipae (Keifer) in leek. European Journal of Plant Pathology, 157, 215-222.

Debnath P., \& Karmakar K. (2013). Garlic Mite, Aceria Tulipae (Keifer) (Acari: Eriophyoidea) - a Threat for Garlic in West Bengal, India. International Journal of Acarology, 39, 89-96.

Gispert, C., Oldfield, G. N., Perring, T. M., \& Creamer, R. (1998). Biology of the transmission of peach mosaic virus by Eriophyes insidiosus (Acari: Eriophyidae). Plant Disease, 82, 1371-1374.

Karpicka-Ignatowska, K., Laska, A., Kuczyński, L., Rector, B. G., Lewandowski, M., Puchalska, E., \& Skoracka, A. (2019). A novel experimental approach for studying life-history traits of phytophagous arthropods utilizing an artificial culture medium. Scientific Reports, 9, 1-9.

Keifer H.H. (1952). The eriophyid mites of California (Acarina: Eriophyidae). Bulletin of the California Insect Survey, 2, 1-123.

Kiedrowicz, A., Szydło, W., \& Skoracka, A. (2017). Population growth rate of dry bulb mite, Aceria tulipae (Acariformes: Eriophyidae), on agriculturally important plants and implications for its taxonomic status. Experimental and Applied Acarology, 73, 1-10.

Knoell, E. A. (2018). Transmission Characteristics of Triticum mosaic virus by the Wheat Curl Mite Aceria tosichella Keifer and Ecology of the Wheat-Mite-Virus Complex on Field Corn. Dissertations and Student Research in Entomology University of Nebraska-Lincoln.

Kulkarni, N. K., Kumar, P. L., Muniyappa, V., Jones, A. T., \& Reddy, D. V. R. (2002). Transmission of Pigeon pea sterility mosaic virus by the Eriophyid Mite, Aceria cajani (Acari: Arthropoda). Plant Disease, 86, 12971302. 
Manson, D. C. M. \& Oldfield G. N. (1996). Life forms, deuterogyny, diapause and seasonal development. In: Lindquist, E.E., Sabelis, M.W. \& Bruin, J. (eds.) Eriophyoid Mites - Their Biology, Natural Enemies and Control. World Crop Pests Vol 6. Elsevier Science Publishing, Amsterdam, The Netherlands, 173-183.

Murashige, T. \& Skoog, F. (1962). A Revised Medium for Rapid Growth and Bioassays with Tobacco Tissue Cultures. Physiologia Plantarum, 15, 473-497.

Orlob, G. B. 1966. Feeding and Transmission Characteristics of Aceria tulipae Keifer as Vector of Wheat Streak Mosaic Virus. Journal of Phytopathology, 55, 218-238.

Paduch-Cichal, E., \& Bereda, M. (2017). Viruses infecting ornamental Allium species in Poland. Journal of Plant Pathology, 99, 509-512.

Park, K. S., Bae, Y. J., Jung, E. J. \& Kang, S. J. (2005). RT-PCR-based detection of six garlic viruses and their phylogenetic relationships. Journal of Microbiology Biotechnology, 15, 1110-1114.

Sánchez-Sánchez, H., Henry, M., Cárdenas-Soriano, E., \& Alvizo-Villasana, H. F. (2001). Identification of Wheat streak mosaic virus and its vector Aceria tosichella in Mexico. Plant Disease, 85, 13-17.

Sapáková, E., Hasíková, L., Hřivna, L., Stavělíková, H., \&Šefrová, H. (2012). Infestation of different garlic varieties by dry bulb mite Aceria tulipae (Keifer) (Acari: Eriophyidae). Acta Universitatis Agriculturae et Silviculturae Mendelianae Brunensis, 60, 293-301.

Seifers, D. L., Harvey, T. L., Louie, R., Gordon, D. T., \& Martin, T. J. (2002). Differential transmission of isolates of the High Plains virus by different sources of wheat curl mites. Plant Disease, 86, 138-142.

Stenger, D. C., Hein, G. L., Tatineni, S., \& French, R. (2016). Eriophyid mite vectors of plant viruses. Chapter 18, 263-274. In: Vector-mediated transmission of plant pathogens. Brown, J. K. (ed.), APS Press.

Van Dijk, P., Verbeek, M., \& Bos, L. (1991). Mite-borne virus isolates from cultivated Allium species, and their classification into two new rymoviruses in the family Potyviridae. European Journal of Plant Pathology, 97, 381-399. 